\title{
Acute Clinically Mastitic Animals in villages of Assiut Governance: Diagnosis and Treatment
}

\author{
Mohammad Sayed and Ahmed Abdel Rady ${ }^{1}$ \\ Department of Food Hygiene, \\ Faculty of Veterinary Medicine, Assiut University, Assiut, EGYPT.
}

\begin{abstract}
This investigation was run in some villages in Assiut governorate during summer 2007 to diagnose acute clinical mastitis in different animal species and to apply different lines of treatment for evaluating which treatment line of choice giving cure, aiming to another goal by preventing the conversion of acute mastitis towards the chronic one which is difficult to be treated and the dairy animal will be excluded. Therefore, 2150 animals were clinically examined in 5 villages located north to Assiut city, Egypt, including 400 cows, 950 ewes and 800 she goats, and the incidence of acute clinical mastitis was $22.50 \%, 2.63 \%$ and $4.63 \%$, respectively. Milk samples were collected from all clinically mastitic cows for bacteriological examination to identify the causative agents of the intra-mammary infection (IMI). It was found the major causative agents isolated were Staphylococcus aureus, Streptococcus agalactiae, Escherichia coli and Corynebacterium pyogenes, causing either single or mixed type of infection. When applying different lines of treatment, all diseased animals were classified into 3 groups: 1st group received local treatment by intra-mammary infusion antibiotic. 2nd group received systematic treatment by intra-muscular (I/M) injection of both antibiotic and anti-inflammatory drugs. While, 3rd group received combination of both local and systematic treatment lines together. Cure\% was achieved as $50 \%$ for 1 st group, $90 \%$ for 2nd group, while 3rd group gave complete cure by $100 \%$. It was noticed that the incidence of acute clinical mastitis among examined cows was worrisome and can be considered as indicator of the epidemiology of the disease. While, spreading of the disease among ewes and she goats was somewhat low in comparison with that of cows. In conclusion, combination of both local and systematic treatment lines together should be advised in treatment of acute clinical mastitis to ensure complete cure. The obtained results highlighted the focus towards the spreading of acute clinical mastitis among cows lived in some Assiut governorate villages.
\end{abstract}

Key words: Acute clinical mastitis, Cows, Ewes, She goats, Intra-mammary infection (IMI).

\section{Introduction}

Mastitis in dairy cows is a serious problem as it is an economically devastating disease causing immense economic losses in the dairy industry in Egypt (Seleim et al., 2002) and is the worldwide costliest production disease in dairy herds (Miller et al., 1993). Annual losses in the dairy industry due to mastitis were approximately 2 billions dollars in USA and 526 millions dollars in India (Varshney and Naresh, 2004).

Mastitis is a widely health problem does not only causes economic disease-related losses in dairy herd farm, but it is also responsible for extended usage of antibiotics in these enterprises (Kromker and Grabowski, 2002).

Economical losses were summarized by Harmon (1994) and Barmely et al. (1996) including loss in milk production, discarding abnormal milk \& milk withheld from cows treated with antibiotics, degrading of milk quality and price due to high bacterial or somatic cell count (SCC), costs of drugs, veterinary services \& increased labor costs, increased risk of subsequent mastitis, herd replacement, and problems related to antibiotics residues in milk \& its products.

The acute clinical mastitis is the most observable form which characterized by udder swelling, firmness, redness, painful, hotness and the animal can show hyperthermia (Schweizer, 1973).

According to the aforementioned causes, this investigation was run to determine the incidence of acute clinically mastitic animals in some villages of Assiut governorate from the points of diagnosis 1. Department of Animal Medicine, Faculty of Veterinary Medicine, Assiut University, Assiut, Egypt. 
and treatment view. As mastitis is one of the most costly and troublesome diseases in dairy cows in Egypt (Seleim et al., 2002), choosing the lines of choice for treatment is reasonable, advisable and required.

\section{Material and Methods}

Animals: During summer 2007, a total of 2150 animals distributed in 5 villages located north to Assiut city, Egypt, were examined physically for acute clinical mastitis based on any observable signs in the udder and/or milk and delivered for bacteriological examination. All the examined animals were classified into 400 cows, 950 ewes and 800 she goats. All ewes and she goats were of native breed, while cows included 267 as Friesian breed and 133 as native breed. They lived nearly under the same conditions of breeding from the habitat, hygiene and feeding systems.

Milk samples: After discarding the first few milk squirts, milk samples were taken from all clinically mastitic cows. In a clean environment, thoroughly wiping the teats with $70 \%$ ethyl alcohol with paying extra attention to teat orifice was applied.

Bacteriological examination: Each milk sample was collected under aseptic conditions in a sterile screw caped bottle. All milk samples were sent directly to the laboratory with a minimum of delay for routine culture techniques.

Milk samples were cultured onto $10 \%$ sheep blood agar and MacConkey agar plates according to Carter and Cole (1990). Suspected colonies were identified morphologically, microscopically and biochemically according to Quinn et al. (1994) and Waage et al. (1999).

Treatment lines: All the diseased animals were subjected to different lines of treatment in 3 groups: 1 st group was represented as 30 cows received local treatment by intra-mammary infusion antibiotic (Tetra-DeltaTM, Upjohn), once daily for 5 successive days. 2nd group was represented as 30 cows received systematic treatment by $\mathrm{I} / \mathrm{M}$ route of both antibiotic (ExcenelTMRTU, Pfizer) and antiinflammatory drugs (Predef 2X, Upjohn), once daily for 5 successive days. 3rd group was represented as 30 cows, 25 ewes and 37 she goats, received combination of both local and systematic treatment lines of 1st and 2nd groups together, once daily for 5 successive days.

\section{Results}

1. Incidence of diseased animals with acute clinical mastitis: Clinically diseased animal with acute mastitis was detected by clinically infected quarters often showing moderate swelling, firmness, visible signs of chunks of milk, clots in milk and some cases milk become viscous. 90 out of total 400 examined cows $(22.5 \%)$ were diseased. The incidence according to their breed was $22.47 \%$ for Friesian and $22.56 \%$ for native. Low percentages in both ewes and she goats were obtained as 2.63 and $4.63 \%$, respectively (Table 1 ).

Table 1. Incidence of diseased animals with acute clinical mastitis.

$\begin{array}{llccc}\text { Species } & \text { Breed } & \begin{array}{c}\text { Total } \\ \text { No. }\end{array} & \begin{array}{c}\text { Diseased } \\ \text { No. }\end{array} & \begin{array}{c}\text { Diseased } \\ \%\end{array} \\ \text { Cows } & \text { F + Native } & 400 & 90 & 22.5 \\ & \text { Friesian } & 267 & 60 & 22.47 \\ \text { Ewes } & \text { Native } & 133 & 30 & 22.56 \\ \text { She goats } & \text { Native } & 950 & 25 & 2.63 \\ & \text { Native } & 800 & 37 & 4.63\end{array}$

2. Bacteriological results: All the mastitic cows milk samples were positive for isolation and identification of several bacterial organisms (bacterial mastitis) as presented in Table 2. Bacterial analysis results showed 4 dominating bacterial species. They were Staphylococcus aureus, Streptococcus agalactiae, Escherichia coli and Corynebacterium pyogenes which were isolated from $45,25,13$ and 7 of acute clinically mastitic cows, respectively. Each causative agent

Table 2. Different types of bacterial infection in acute clinical mastitic cows.

\begin{tabular}{|l|c|c|l|}
\hline Causative agent & $\begin{array}{c}\text { Acute clinically } \\
\text { Mastitic cows }\end{array}$ & Incidence & Type of infection \\
\hline Staph. aureus & 45 & 37 & Single \\
& & 6 & Mixed with Strept. agalactiae \\
Strept. agalactiae & 25 & 2 & Mixed with C. pyogenes \\
& 19 & Single \\
E. coli & 13 & 6 & Mixed with Staph. aureus \\
C.pyogenes & 7 & 5 & Single \\
& & 2 & Single \\
\hline
\end{tabular}


Acute Clinically Mastitic Animals in villages of Assiut Governance: Diagnosis and Treatment

Table 3. The relation between treatment lines and cure \%.

\begin{tabular}{|l|l|c|c|c|c|}
\hline Treatment lines & Drug types & Animals & Cure No. & Diseased No. & Cured \% \\
\hline $\begin{array}{l}\text { 1st } \\
\text { (Local) }\end{array}$ & $\begin{array}{l}\text { Intra-mammary infusion } \\
\text { antibiotic1 }\end{array}$ & Cows & 30 & 15 & 50 \\
\hline 2nd & I/M injection of both antibiotic2 & Cows & 30 & 27 & 90 \\
(Systematic) & and anti-inflammatory drugs3 & & & & \\
\hline 3rd & Combination of both 1st \& & Cows & 30 & 30 & 100 \\
(Both 1st \& 2nd) & 2nd together & Ewes & 25 & 25 & 100 \\
& & She goats & 37 & 37 & 100 \\
\hline
\end{tabular}

1. Tetra-DeltaTM, Upjohn,

2.

ExcenelTMRTU, Pfizer,

3. Predef 2X, Upjohn

was found either in single or mixed infection with other detected microorganisms, except $E$. coli which was found in single infection only as shown in Table 2.

3. Effect of different lines of treatment and cure\%: Three different treatment lines were applied for 3 groups of diseased animals; each treatment line was corresponding to each group. 1st group showed 50\% cured and 2nd group showed $90 \%$ cured. While, 3rd group showed complete cure (Table 3).

\section{Discussion}

This investigation was aimed to study the prevalence of the acute form of clinical mastitis because it is the more visible form than other forms of mastitis, in which, its presence in high percentage reflect the spreading of other forms of mastitis such as subclinical and chronic that may be present also, in which, the subclinical form is considered 15-40 times more prevalent than the clinical form (Harmon, 1994). Unfor-tunately, most infections are not detected until they become clinical, and by then extensive and costly damage can result. It was obvious from the obtained results in Table.1, that about quarter of the examined cows $(22.5 \%)$ were diseased, other-wise, the rest of animals did not showed the acute form of clinical mastitis but may had mastitis in other forms. That is mean if percentages of other forms of mastitis would be added to the obtained one (22.5\%), the mastitis will cover most of the animal populations in the villages of the present investigation. Therefore, the spreading of the acute form of clinical mastitis among cows is a warning message to organize control programs for mastitis not only for acute form but for other forms of mastitis. As acute form of clinical mastitis is the most prominent visible form to be diagnosed than other forms, the bacteriological examination should be run because it is still the most suitable, accurate and reliable method to confirm the IMI (El-Balkemy et al.,1997). Additionally, many investigations (NMC,1999; Dingwell,et.al.,2003; Milne et al., 2003) had assured that bacteriological culture is the gold standard method for identifying the IMI and routine milk cultures should be an ongoing part of any mastitis control program. As bacteria are the most frequent causes of the IMI (Sargeant,et.al., 2001), Staphylococcus aureus, Streptococcus agalactiae and $E$. coli are the most common etiological agents involved in subclinical and clinical cases of mastitis in dairy cows (Gonzalo,et.al., 2002). Radostits, et. al. (2000) considered Staph. aureus and Strept. agalactiae, the causes of contagious mastitis, while, Pseudomonas aeroginosa, C. pyogenes and some Aerobacter spp. are less common (Haynes, 1985). According to the obtained bacteriological results in the present work (Table 2), Staph. aureus and Strept. agalactiae were isolated from most of the diseased cows from 45 and 25 animals, respectively, and 6 cows had mixed infection. That may be attributed to Staphylococciand Streptococci cause $90 \%$ of bovine mastitis (Poutrel, 1983). E. coli and $C$. pyogenes were isolated from the rest 20 diseased cows as 13 and 7, respectively. None of bacteriologically negative samples were found, agreed with that recorded by Gregory and Hoedemaker (2002). Mastitis considered as multifactorial disease where development of IMI depends on presence of mastitic pathogens and a series of additional factors that act concomitantly. The prevalence of acute mastitis in this work among all clinically mastitic cows was caused by environmental bacterial clinical mastitis including Staph. aureus, Strept. agalactiae and E.coli. Furthermore, additional factors of breeding where the cows lived including bad habitat, lack of hygiene, unbalanced food and bad draft, in which these defective conditions played a role in rendering 
udder more susceptible to IMI (Ghazi and Niar, 2006). On the other hand, good management practices such as milker hygiene and udder healthy environment as well as dry off treatment and controlling other predisposing diseases should be considered among the major prophylactic measures to minimize the occurrence of the disease. In order to minimize the damage revealed from clinical mastitis it is necessary to focus on preventive actions at the farm-medical level rather than to resort to syringe and antibiotics (Ahmed,et. al., 2006). Another goal of this work was studying the efficiency of different lines of treatment to gain complete cure for all diseased animals. Therefore, 3 different treatment lines including local, systematic and combination of both local and systematic together were applied and detailed in Table. 3. First treatment line was local by applying intra-mammary infusion antibiotic and was chosen for 30 diseased cows as 1st group, in which local treatment may be sufficient to induce cure for this group as one quarter only was affected. With observation the cure\%, it was found 15 cows $(50 \%)$ showed cure but the second half still undergo affection. 2nd treatment line was systematic by applying I/M route of both antibiotic and anti-inflammatory drugs and was chosen for 30 diseased cows as 2nd group, in which this systematic treatment may be able to relief the affection from the whole udder. High percentage as $90 \%$ (27 cows) of this group showed cure because this treatment line is systematic and also a combination between antibiotic and antiinflammatory drugs was applied. But $10 \%$ was still diseased and may be cured with 3rd treatment line for 3rd group. 3rd treatment line was a combination of both 1 st and 2 nd lines together and was chosen for the rest 30 diseased cows as 3rd group, thus, they were put in comparison with 2nd group treated with the systematic line only for evaluating 2 nd and 3 rd treatment lines. It was noticed that all 30 (100\%) diseased cows were cured as was expected because the combination of both local beside systematic lines together was more and more effective. Therefore, during application of this investigation, all diseased ewes and she goats were added to 3rd group and treated with 3rd treatment line and the cure $\%$ obtained was also $100 \%$. The conclusion extracted here is the combination of both local and systematic treatment lines is effective although it is apparently more costly, but it is really cheaper because gaining the complete cure. That is the answer of the question in this situation: which cheaper more treatment with complete cure or less treatment with a percentage of a cure?

\section{References}

1. Ahmed, Eman A.et.al.(2006): Assiut Vet. Med. J. 52:207.

2. Bramely, A.J.et.al. (1996): Current concepts of bovine mastitis. 4th Ed. National Mastitis Council, Inc.

3. Arlington, VA. Carter, G.R. and Cole, J.R.J. (1990): Diagnostic procedures in veterinary bacteriology and mycology. Essentials of veterinary bacteriology and mycology. 5th Ed. Academic press, USA.

4. Dingwell, R.T.et.al. (2003): Can. Vet. J. 44:413.

5. El-Balkemy, F.A.; Esmat, M.; Menazie, Afaf and Farag, Azza N. (1997): Evaluation of screening tests used for detection of subclinical mastitis. 4th Sci. Cong. Egyptian Society for Cattle Diseases, Assiut, Egypt. pp 181.

6. Ghazi, K. and Niar, A. (2006): Assiut Vet. Med. J. 52:198.

7. Gonzalo, C. ; Ariznabarrta, A. and Carriedo, J.A. (2002): J. Dairy Sci. 85:1460.

8. Gregory, A. and Hoedemaker, M. (2002): Bovine catarrhal mastitis: frequency, etiology and therapy. In the proceedings of XXII World Buiatrics Congress, Hanover, Germany. 1823 August 2002.

9. Harmon, R.J. (1994): J. Dairy Sci. 77:2103.

10. Haynes, N.B. (1985): Diseases caused by bacterial mastitis in keeping life stock healthy. Ed. by Haynes, story communication inc. Pawnal Vermont 052.

11. Miller, R.H.; Pape, M.J.; Fulton, L.A. and Schutz, M.M. (1993): J. Dairy Sci. 76:728.

12. Milne, M.H.et.al.(2003): Vet. Rec. 152:615. 12. NMC (National Mastitis Council) (1999): Laboratory Handbook on Bovine Mastitis, revised ed. Madison, Wisconsin: Nalt Mastitis Counc, Inc., pp. 1.

13. Poutrel, B. (1983): Amer. J. Vet. Res. 44:490.

14. Sargeant, J.M.et.al.(2001): J. Dairy Sci. 84:2018.

15. Seleim, R.S.; Rashed, Amany Y.M. and Fahmy, B.G.A. (2002): Vet. Med. J. Giza, 50:405. 17.

16. Varshney, J.P. and Naresh, R. (2004): Homeopathy, 93:17.

17. Waage, S.et.al.(1999): J. Dairy Sci. 82:712. 